\title{
The Role of Corporate Governance in Initial Public Offerings: Evidence from Real Estate Investment Trusts
}

\author{
Jay C. Hartzell University of Texas at Austin
}

Jarl G. Kallberg Thunderbird School of Global Management

Crocker H. Liu Arizona State University

\begin{abstract}
This study analyzes the impact of corporate governance structures at the initial public offering (IPO) date. We test hypotheses that firms with more shareholderoriented governance structures receive higher valuations at the IPO stage and have better long-term performance. Our sample is a set of 107 IPOs of real estate investment trusts (REITs) between 1991 and 1998. Using a single industry and REITs in particular reduces potentially confounding effects due to differences in risk, transparency, and growth potential. We believe this-combined with our use of IPOs-mitigates the endogeneity problem present in studies of the impact of governance on seasoned firms' valuation. Our analysis indicates that firms with stronger governance structures have higher IPO valuations and better long-term operating performance than their peers.
\end{abstract}

\section{Introduction}

The separation of ownership and control of the firm provides much of the impetus for corporate governance. To mitigate these conflicts between shareholders and managers, many control mechanisms have been devised, including compensation contracts, board structures, antitakeover provisions, ownership

We are grateful to William Allen, Laura Starks, Sheridan Titman, our discussant, Joe Gyourko, and seminar participants at the 2003 American Finance Association meetings in Washington, D.C.; to Tim Riddiough and conference participants at the 2002 Vail Real Estate Research Conference; and to Robert Edelstein, Will Goetzmann, and conference participants at the 2002 Asia Pacific Finance Association meetings in Tokyo for comments. We thank Murat Binay and Sanjay Sharma for research assistance. Finally, the comments of an anonymous referee have been very useful in improving this study. All errors remain our own.

[Journal of Law and Economics, vol. 51 (August 2008)]

(C) 2008 by The University of Chicago. All rights reserved. 0022-2186/2008/5103-0020\$10.00 
structure, and takeovers. ${ }^{1}$ However, continuing debate exists on the impact of these choices on firm valuation and operating performance. ${ }^{2}$

The main purpose of our study is to examine how differences in the governance structures of firms at the time of their initial public offerings (IPOs) influence their initial market valuations. A potentially important implication of these differences is that any negative IPO valuation effects are borne by the firm and its insiders through a reduction in the offering's proceeds. Thus, a positive relation between the strength of corporate governance and firm valuation at the time of the IPO is consistent with insiders' willingness to trade looser monitoring of their activities for lower cash proceeds. This potential loss of firm value provides an estimate of the magnitude of agency trade-offs to firm insiders. Our focus on IPOs allows us to examine the role of governance at the beginning of the firm's life as a public corporation. ${ }^{3}$ Firms with weaker (that is, less shareholderoriented) governance at the time of the IPO could receive lower valuations either from lower expected cash flows (because investors expect management to divert a portion of the profits or to invest suboptimally owing to private benefits $)^{4}$ or from higher (priced) risk. ${ }^{5}$ We also test a related hypothesis: stronger governance structures at the time of the IPO are associated with better post-IPO operating performance.

Our tests use a sample of IPOs of real estate investment trusts (REITs). Our analysis indicates that a REIT's governance structure at the time of the IPO is an important determinant of its initial value and future operating performance. We find that REITs with stronger governance structures not only have higher initial IPO valuations (that is, Tobin's $Q$ ) but also have better long-term operating performance. This effect is significant in both a statistical and an economic sense. We find that increases in managerial incentives via either insider ownership (up to a point) or variable compensation are associated with significant increases in

${ }^{1}$ See Shleifer and Vishny (1997) for a review of the corporate governance literature. Holmström (1979) and Jensen and Murphy (1990) provide examples of theoretical and empirical work on compensation contracts. Hermalin and Weisbach (2003) review the role of the board.

${ }^{2}$ One relevant example is the controversy surrounding the relation between managerial ownership and the value of the firm as measured by Tobin's Q. Mørck, Shleifer, and Vishny (1988) find a nonmonotonic relation between managerial ownership and the market value of the firm (using Tobin's $Q$ as a proxy), which they argue is due to competing effects of incentive alignment and management entrenchment (or deviation from value-maximizing behavior). More recent studies have debated the role of endogeneity in this relation (Himmelberg, Hubbard, and Palia 1999; Zhou 2001). Other research has shown that control mechanisms affect firm value (see, for example, Jarrell and Poulsen 1987). Yermack (1996) provides evidence that smaller boards are associated with higher valuations and higher values of Q. Fueling the debate further, Agrawal and Knoeber (1996) show that, since the alternative control mechanisms are interdependent, the impact of a single control mechanism on firm performance (again measured by Tobin's $Q$ ) is potentially misleading.

${ }^{3}$ For a discussion of how and why governance changes following an IPO, see Frye (2002).

${ }^{4}$ Brennan and Franks (1997) discuss insiders' use of IPO governance structure to preserve their private benefits of control.

${ }^{5}$ However, as noted in Field and Karpoff (2002, p. 1885), "The existence of agency costs at the IPO stage does not necessarily represent an inefficiency. We would expect pre-IPO investors to pay prices for shares that reflect the expected costs of agency, just as they reflect such other costs as labor and capital." 
$Q$ as of the IPO offer price. Incorporation in Maryland-a state known to be management friendly for investment trusts and investment firms-is associated with lower valuations. We also find that valuations decrease with the number of management-friendly corporate charter provisions (for example, antitakeover devices) that a firm has in place as of the IPO date. ${ }^{6}$

In support of our second hypothesis, we show that operating performance (as measured by return on book equity) is also positively influenced by shareholderoriented governance structures. Increased amounts of insider ownership and a higher fraction of variable compensation at the time of the IPO are both positively related to operating performance for up to 12 post-IPO quarters. Also consistent with the valuation results, incorporation in Maryland is negatively related to subsequent operating performance.

Like many of the related studies on the effect of governance on value, we use Tobin's $Q$ as our proxy for stock market valuation to mitigate the need for risk adjustment. ${ }^{7}$ But we believe that our study design has several advantages over the more common approach of testing for a cross-sectional relation between $Q$ and governance in a broad set of firms. First, we focus on one industry and control for common time effects so that any observed differences in $Q$ can be more properly interpreted as differences in valuation rather than variations in growth prospects or risk. This should also reduce noise across our sample and potentially increase the power of our tests.

Second, we use REITs, a natural industry to study the questions at hand. Ideally, to test for a relation between governance and valuation, one would like an industry where (1) firms face similar investment opportunities (so differences in $Q$ could be attributed to valuation effects), (2) investors understand how to value the firm (and its projects), and (3) despite the similarity in prospects and projects, firms exhibit a wide range of governance choices. Real estate investment trusts fit these criteria well. To check the validity of the first two of these criteria, we compared a rough estimate of prediction errors for REIT IPO pricing to those documented by Kim and Ritter (1999) for general corporations. Using the median $Q$ for all seasoned REITs to predict a REIT IPO's Q, our mean absolute prediction error is less than half as large as found in Kim and Ritter: 19 percent (median of 21 percent), with almost twice as many (more than 40 percent) of the errors within 15 percent of the actual price. ${ }^{8}$ Thus, REITs appear relatively easy to value, even using simple comparables, and exhibit less cross-sectional

\footnotetext{
${ }^{6}$ When we measure $Q$ at the end of the first trading day, we find similar results, which suggests that the positive impact of a strong governance structure extends beyond the establishment of the offer price.

${ }^{7}$ Lang and Stulz (1994) argue that since $Q$ is the ratio of the present value of the firm's future cash flows to the replacement value of its assets, risk adjustments are already incorporated.

${ }^{8}$ Except for our use of the median seasoned firm ratio rather than a recent IPO ratio and our use of $Q$ rather than their use of market-to-book, we calculate these prediction errors in the same way as Kim and Ritter (1999): the natural logarithm of the median of the comparable firms' multiple, minus the natural logarithm of the IPO firm's multiple. Absolute prediction error is just the absolute value of this difference.
} 
variation in pricing, consistent with more homogeneous growth opportunities. A further implication of using REITs is that because of legal (tax) restrictions (outlined briefly in Section 2 and in the Appendix), corporate governance is likely to be less important for REITs than for other corporations. As such, if we find that governance characteristics influence REIT valuation and performance, then this effect should be at least as strong for other types of corporations.

Third, by analyzing the governance structure at the IPO date rather than later in the firm's life, the timing of the relation between governance and valuation is clearer, which should lessen some of the endogeneity problems associated with Q. For mature firms, it can be difficult to distinguish between governance driving differences in valuation versus differences in valuations driving the choice of governance structure.

By focusing on IPOs, our study complements current research on the impact of governance structure at the IPO stage. Daines and Klausner (2001) examine the bylaws and charters of 310 IPOs. They find that over two-thirds of the firms in their sample have antitakeover provisions (ATPs). They argue that putting ATPs in place at the time of the IPO is more likely to be an effort to entrench management rather than maximize value. Field and Karpoff (2002) reach a similar conclusion in their analysis of a sample of 1,019 IPOs from 1988 to 1992. Like Daines and Klausner, they find extensive use of ATPs at the IPO stage. They find that the use of ATPs at the IPO stage is associated with a lower likelihood of being acquired. They find no correlation between post-IPO operating performance and ATP adoption. They conclude that "managers appear to shift the cost of takeover protection onto non-managerial shareholders" (Field and Karpoff 2002, p. 1884). ${ }^{9}$ Smart and Zutter (2003) analyze a sample of 253 dualclass and 2,369 single-class IPOs. They show that dual-class IPOs obtain lower price-sales multiples at the time of the IPO. Baker and Gompers (2003) view the structure of the board of directors at the time of the IPO as an outcome of a bargaining game between management and outside shareholders. They find that the presence of venture capitalists in the firm acts as a balance to chief executive officer (CEO) power.

While these studies provide important insights into the issue of governance structure and valuation at the IPO stage, our analysis builds on these papers in at least two important dimensions. First, while Daines and Klausner (2001) and Field and Karpoff (2002) use several antitakeover provisions and Baker and Gompers (2003) analyze the board of directors, they all leave open the question of the impact of these provisions on valuation as of the IPO date. Smart and Zutter (2003) do address valuation effects as of the IPO date, but their featurethe presence of unequal voting rights-is a relatively infrequent and extreme control mechanism. Second, we analyze a broader set of governance mechanisms

\footnotetext{
${ }^{9}$ Baranchuk, Kieschnick, and Moussawi (2006) argue that ATPs act as a substitute to compensation in growth firms in providing managerial incentives. They find no relation between the initial valuation of IPOs and ATP adoption in their sample.
} 
and their effects on IPOs instead of focusing solely on corporate control provisions (as in Daines and Klausner [2001], Field and Karpoff [2002], and Smart and Zutter [2003]), or the board (as in Baker and Gompers [2003]). ${ }^{10,11}$

Our paper is organized as follows. Section 2 presents an overview of REITs, including management types, differences in compensation contracts, and the associated corporate control issues. Section 3 describes the sample. Section 4 reports our findings on the impact of corporate governance structures on the initial value of an IPO and its long-term operating performance. Section 5 concludes.

\section{Real Estate Investment Trusts' Corporate Governance Structure}

While analyzing governance variables that relate to the monitoring and incentive structure of the firm, we control for other important REIT characteristics. This section provides a brief overview of the REIT characteristics most relevant to our empirical analysis. Further details and a description of the umbrella partnership REIT (UPREIT) structure are given in the Appendix.

\subsection{Legal Restrictions}

Because of REIT legal requirements, the amount of managerial discretion that REIT managers wield is significantly less than in regular corporations. First, to qualify as a REIT, a company must distribute at least 95 percent of its taxable income (excluding net capital gains) as dividends. ${ }^{12}$ Since managers of REITs have less discretion over their cash flows than do regular corporations, this payout requirement mitigates agency problems (see Jensen 1986). However, the payout requirement restricts a REIT's ability to fund growth internally through retained earnings. Wang, Erickson, and Gau (1993) find that REITs generally pay out more than 95 percent of their taxable income as dividends. ${ }^{13}$ As a result, REITs must frequently raise external capital. The market for these secondary equity and debt issues acts as a monitoring mechanism for a REIT following its IPO.

A second restriction is on ownership. The Internal Revenue Code restricts the five largest shareholders of a REIT to controlling (directly or indirectly) no more than 50 percent of the REIT's shares (known as the 5-50 rule). Many REITs have a provision in their articles of incorporation that permits five persons to acquire up to a maximum of 9.8 percent each. While this restriction might imply a greater need for corporate governance (for example, because of the lack of large shareholders with incentives to monitor), there are two important countervailing

\footnotetext{
${ }^{10}$ Gillan, Hartzell, and Starks (2006) present evidence that by looking at alternative governance mechanisms, one can obtain quite different impressions of the strength of a firm's governance structure.

${ }^{11}$ Field and Karpoff (2002) use additional governance variables-managerial ownership and compensation, and the structure of the board-to help explain the adoption of antitakeover provisions.

${ }^{12}$ This was reduced to 90 percent in 2000, but this change occurred too late to affect our results.

${ }^{13}$ Kallberg, Liu, and Srinivasan (2003) show that, for the largest REITs, the median dividend payout is 111 percent of taxable income.
} 
issues. First, institutional holdings are not regarded as a single investor for purposes of this rule, which allows them to serve a monitoring function. ${ }^{14}$ Second, partially because of the ownership restriction, REIT insiders typically own a small number of REIT shares. In our sample, the median insider ownership is 15.4 percent of the outstanding common stock (20.1 percent mean) at the IPO.

We expect the initial value ( $Q$ ratio) to increase as management increases its ownership in the firm in accordance with the agency theory of Jensen and Meckling (1976). However, Han (2006), studying the interaction between insider ownership and performance of 156 REITs over the period 1994-2000, finds a nonlinear relation between $Q$ and insider ownership. This finding is similar to that of Mørck, Shleifer, and Vishny (1988) for general equities. Mørck, Shleifer, and Vishny highlight a negative aspect of insider ownership arising from possible entrenchment of management with relatively high insider holdings. They note that this entrenchment can lead to a lower valuation of the firm because entrenched management is less aligned with shareholder interests. Stulz (1988) applies a related argument to the market for corporate control, arguing that high levels of insider ownership have a negative impact on the probability of a takeover, again lowering the value of the firm. More recently, Lan and Wang (2004) provide a theoretical model that shows that high levels of insider ownership can lead to overinvestment, which again lowers firm value.

\subsection{Management Style}

Real estate investment trusts employ two basic management structures: internal management, where managers are employees of the firm, and external or advisor management, where managers are employees of an independent advisory firm. Prior to 1991, all REITs were externally advised at the time of their IPO. ${ }^{15}$ In our sample, 89 percent of the REITs were self-advised at the time of the IPO. Managers of advisor REITs are frequently allowed to set up independent companies to buy or sell assets and goods and services to the REIT, thus increasing the opportunities for managerial expropriation of funds and self-dealing. We therefore include an indicator variable for internally managed REITs in our tests and expect that these REITs should have a higher Tobin's $Q$ than advisor REITs. Because this incentive alignment is likely to affect future cash flows, we would also expect better long-term operating performance for self-advised relative to advisor REITs.

\footnotetext{
${ }^{14}$ Prior to 1993 , each institutional investor was regarded as a single stockholder with respect to the 5-50 rule. The 1993 tax law created a "303look-through" provision that permitted institutional holdings to be allocated among their beneficiaries. A consequence of this prior ruling was that institutional holdings were relatively small and institutions played a limited role prior to 1993 .

${ }^{15}$ While self-advised REITs appeared as early as 1986 as the result of private-letter rulings from the Internal Revenue Service, these firms were existing REITs that changed from external management to internal management.
} 


\subsection{Compensation Structure}

Conflicts can arise from the compensation arrangements of the REIT advisor. Compensation agreements are important because management fees represent the single largest expense item (after interest expense) in many REITs' income statements. Real estate investment trusts use three general types of compensation arrangements: compensation that is independent of operating performance, based on the REIT's performance, or combinations thereof. ${ }^{16}$ Jenkins (1980) and Capozza and Seguin (2000) show that the type of compensation arrangement used can create a moral hazard problem by inducing a manager to increase the firm's leverage in order to increase her compensation. ${ }^{17}$ As such, we control for a REIT's debt-to-equity ratio in examining the relation between a REIT's corporate governance structure and its IPO performance, in addition to explicitly examining the impact of compensation structure.

\subsection{State of Incorporation}

Aside from compensation and stock ownership, another governance mechanism is the market for corporate control. Takeovers are a disciplinary device (see, for example, Mørck, Shleifer, and Vishny 1988). If managers can take steps to insulate themselves from this threat, then they may be better able to take actions that are self-serving in nature (rather than in shareholders' interests). One way managers can choose to protect themselves is by opting to incorporate in a more manager-friendly state. For REITs, the state that is a common home for incorporations is Maryland, which provides strong antitakeover protection (for example, by allowing for supermajority provisions, explicitly allowing dualclass shares, requiring 100 percent consent for shareholder action by written consent, and not requiring annual shareholder meetings). This not only promotes management entrenchment but also limits the opportunity of stockholders to realize a takeover premium. ${ }^{18}$

Subramanian (2001) finds that Maryland held the second largest share among U.S. public companies in 2000 after Delaware, although almost all of Maryland's share is attributable to REITs and investment firms. In our sample, 68 percent

${ }^{16}$ Examples of the first type of arrangement include compensation based on a percentage of assets, a percentage of equity, or a fixed fee. The second set of contracts bases compensation on a percentage of REIT income, revenue, or net cash flow. The third (hybrid) set involves payment to the advisor based on a REIT's operational results, typically a participation in net income or cash flow when it exceeds some minimum level, in addition to a fixed fee.

${ }^{17}$ In particular, the use of return on equity as the performance benchmark gives the advisor an incentive to increase the assets of the REITs through leverage, thereby raising advisory fees even though borrowing might be detrimental to REIT shareholders.

${ }^{18}$ These features of Maryland law appear to be well known or at least disclosed. An example is United Dominion Realty Trust in its April 2003 proxy statement proposing a change in incorporation from Virginia to Maryland. For additional evidence on state antitakeover provisions attracting incorporating firms, see Bebchuk and Cohen (2003). 
of the IPO firms chose to incorporate in Maryland. ${ }^{19}$ We include an indicator variable for REITs incorporated in Maryland; we expect that Maryland-based REITs are more insulated from external pressure, so management will be more able to extract private benefits. ${ }^{20}$

\subsection{Taxes}

While REITs are exempt from corporate taxes to the extent that they pay out taxable income as dividends, their valuations are still likely to be affected by tax considerations because of the taxes paid by investors upon receiving distributions from the firm. Gentry, Kemsley, and Mayer (2003) find that a REIT's value is positively related to its tax basis, consistent with investors being willing to pay more for a REIT that will provide better tax shelters for future income or capital gains. In addition, UPREITs have the ability to acquire properties in a way that allows them to defer capital gains taxes, an advantage that Sinai and Gyourko (2004) find is generally capitalized into prices. To control for differences in tax basis and ability to defer capital gains, we use three variables in our tests. First, an indicator for REITs that are new firms as of the IPO is a proxy for firms that are likely to have a higher tax basis (for which we would expect to see higher valuations). ${ }^{21}$ Second, an UPREIT indicator variable captures the valuation impact of the ability to defer capital gains (along with any other UPREIT-specific effects, as we discuss below). Finally, we include an interaction between these two indicator variables because the high-tax-basis advantage of newer REITs should not provide as much benefit to UPREITs (who can defer their capital gains).

\subsection{Related Real Estate Investment Trust Literature}

Our empirical analysis controls for REIT-specific characteristics, such as UPREIT status, tax status, management style (external versus internal advisement), firm size, and leverage. Prior studies of the performance of REITs relative to their organizational form and agency costs have focused on how an existing REIT's organizational form is related to its long-term stock market performance

\footnotetext{
${ }^{19}$ An indicator variable for Delaware incorporation was insignificant in our statistical tests. For evidence that Delaware incorporation is associated with greater firm value for regular $\mathrm{C}$ corporations, see Daines (2001).

${ }^{20}$ Two other features of incorporation in Maryland are worth noting. First, because of the large number of REITs incorporated in Maryland, it has better defined case law than competing states. Second, while Maryland does have the positive benefit to shareholders of no franchise tax, other states such as Massachusetts have this feature as well, so this cannot explain REITs' preference for incorporating in Maryland. Further, such tax benefits are likely to be small (our median firm would face approximately $\$ 60,000$ per year in franchise taxes if it were incorporated in Delaware), and our observed relation between value and the Maryland indicator variable goes in the opposite direction (that is, is negative).

${ }^{21}$ Gentry, Kemsley, and Mayer (2003) use firms' net asset values in their tests, but we do not have those as of the IPO date, so we use this alternative proxy for differences in tax basis.
} 
rather than its relation between initial structure and value. ${ }^{22}$ Although some earlier REIT studies have examined the influence of corporate control mechanisms on performance, they do not consider the impact of management style on IPO performance. ${ }^{23}$ While our study is not the first to investigate the performance of REIT IPOs, the prior literature has concentrated on underpricing. ${ }^{24}$ Our use of Tobin's $Q$ as the valuation metric also distinguishes this from prior REIT studies.

\section{Sample Design and Data}

Our sample of 107 equity REITs is assembled from five sources: various editions of the National Association of Real Estate Investment Trust's Real Estate Investment Trust Handbook (NAREIT 1991-98), the Securities Data Corporation (SDC) database, the SNL REIT database, firms in the 6798 Standard Industrial Classification (SIC) code group in the Compustat, and the Center for Research in Securities Prices (CRSP) databases. The sample is drawn from the period 1991-98 because of the REIT structural changes discussed previously and, most important, the fact that all REITs prior to 1990 were externally advised. The float on most of the earlier REITs and the lack of the later pass-through provision also made it infeasible for institutional investors to hold major positions in them. Information on the price, number of shares, and date of the IPO are taken from various issues of the Investment Dealers' Digest (IDD 1991-98) and the SDC database. Post-IPO financial and stock market data are from CRSP and Compustat. We exclude mortgage REITs and REITs that are not in the CRSP or Compustat databases.

\footnotetext{
${ }^{22}$ Howe and Shilling (1990) document the underperformance of externally managed REITs relative to internally managed REITs. Hsieh and Sirmans (1991) find that this underperformance arises in part from tie-in relationships with external advisors. Cannon and Vogt (1995) demonstrate that this underperformance persists for externally managed REITs, even after adjusting for differences in market risk. Capozza and Seguin (2000) find that underperformance of externally managed REITs stems from management compensation contracts for advisor REITs that create incentives to issue more debt in order to increase their compensation base. They find that these debt contracts are negotiated at above-market rates. They also demonstrate that this underperformance is only partially anticipated by shareholders.

${ }^{23}$ Solt and Miller (1985) and Golec (1994) find that financial performance based on operating results is positively related to compensation contracts. A limitation of both studies is that all REITs examined were externally advised, and thus the authors cannot consider the impact of management style on performance. Damodaran and Liu (1993) show that changes in insider ownership affect the stock performance of REITs by signaling private information. Damodaran, John, and Liu (1997) find that a change in organizational form affects performance. None of the studies investigate return performance at the time of the REIT IPO.

${ }^{24}$ Wang, Chan, and Gau (1992), over 1971-88, find that REIT IPOs suffer a price decline on the first day of trading and in the subsequent 4 months. They attribute this result to the inapplicability of the adverse-selection/winner's curse theories given the scarcity of institutional investors in REIT IPOs over their study period. Ling and Ryngaert (1997), over 1991-94, find that REIT IPOs are underpriced. They attribute this finding to greater institutional investor participation in the REIT IPO market.
} 


\subsection{Dependent Variables}

From these data, we construct our valuation measure, Tobin's $Q$ at the time of the IPO, denoted $Q_{\mathrm{IPO}}$ :

$$
Q_{\mathrm{IPO}}=\frac{\text { offer price } \times \text { shares outstanding }+ \text { total assets }- \text { book equity }}{\text { total assets }} .
$$

Here shares outstanding, total assets, and book equity are taken from the first available post-IPO quarter on Compustat. ${ }^{25}$ Minority interests are included in both the numerator and denominator of $Q$. This is essentially setting the market value of the UPREIT operating partnership (OP) units equal to their book value, which is a reasonable assumption given that many of the UPREIT OP units are issued immediately prior to the IPO, when the properties are transferred to the $\mathrm{OP}^{26}$

We calculate adjusted returns, $\operatorname{AdjRet}_{0}$, as the initial-day return less the return over the same day on a value-weighted index of seasoned REITs, where a seasoned REIT is defined as a REIT that has traded for more than 250 trading days. ${ }^{27}$ To confirm that our results reflect market value rather than just an expectation about the market's willingness to pay the offer price, we also calculate an alternative measure of $Q$ as of the close of the first trading day, $Q_{D A Y}$, by multiplying $Q_{\mathrm{IPO}}$ by $\left(1+\operatorname{Adj}_{\mathrm{Ret}}\right)$. For adjusted operating performance, we use Compustat data to construct return on equity (net income $\div$ book equity) for each of the first 12 post-IPO quarters. ${ }^{28}$ We then adjust these variables for industry and time effects by subtracting the respective median of all REITs for each quarter.

\subsection{Governance Variables}

We utilize two measures of incentive alignment: the percentage of shares held by insiders and the proportion of compensation that is variable or tied to performance. We expect that a higher level of ownership is a sign of greater alignment of incentives and lower agency costs. We obtain the percentage of shares owned by insiders at the time of the IPO (InsiderOwn) from Securities and Exchange Commission (SEC) filings and the SDC and Insider Trading Monitor databases, and we include directors' and executive officers' common shares held as a group in addition to shares that the REIT advisor holds (if the REIT is externally advised). For UPREITs, we include the equivalent number of REIT common shares that would be issued upon conversion of OP units in both the numerator (that is, insiders' shares held) and denominator (that is, total shares outstanding

\footnotetext{
${ }^{25}$ The correlation between this Compustat figure for total assets and pro forma total assets from the IPO prospectus is .998 . We use the Compustat number for total assets for consistency in timing across our accounting items.

${ }^{26}$ These results are robust to excluding minority interests in the calculation of $Q$.

${ }^{27}$ Kallberg, Liu, and Trzcinka (2000) show that, for REITs, this single-factor model performs as well as more general multifactor models.

${ }^{28}$ We obtain qualitatively similar results using return on assets (net income $\div$ total assets).
} 
on a fully diluted basis after all OP units have been converted). To allow for the possibility that too much insider ownership may result in entrenchment (and a loss of value), as noted earlier, we also include the square of insider ownership, InsiderOwn ${ }^{2}$.

In addition to ownership, which represents the level of incentives, we also construct a measure of the flow of incentives based on managers' annual compensation. We would expect that, holding the level of compensation and other variables constant, having a greater fraction of pay tied to performance provides stronger incentives for management. For this second measure of incentives, we first calculate the total dollar value of management compensation and individual compensation components from the annual report and SEC 10-K filings. To measure the proportion of compensation that is incentive based, we construct VarPay, which for adviser REITs equals incentive fees divided by total fees and for self-administered REITs equals (total pay - salary - other benefits) divided by total pay. Our use of both ownership and compensation data to measure incentives is similar to approaches used previously (see, for example, Burns and Kedia 2006).

To measure rent extraction and to control for the level of pay, we calculate a dollar measure of excess compensation, ExcessComp, which is the residual from a regression of TotalCompensation on natural logarithms of market capitalization and total revenue, year dummies, and a dummy for self-administered REITs. ${ }^{29}$ Higher excess compensation can be indicative of greater expected agency costs, or, if markets for corporate compensation are efficient, it can indicate greater managerial ability.

For measures of monitoring, we follow the methodology of Gompers, Ishii, and Metrick (2003) and Bebchuk, Cohen, and Ferrell (2005). The Gompers, Ishii, and Metrick governance index counts the incidence of 24 governance rules; each rule is considered favorable to management. They find that their index is negatively correlated with firm performance, measured by abnormal stock returns or $Q$. We construct a similar governance variable, CharterIndex, following their approach. The elements of our index are a subset of the 24 used in Gompers, Ishii, and Metrick and two that they do not include: a provision for a supermajority for director removal and a miscellaneous antitakeover category. As in Gompers, Ishii, and Metrick, our index counts the incidence of each of the following charter provisions (the value in parentheses represents the relative frequency in our sample): indicators for the presence of a staggered board (69 percent); provisions requiring a supermajority to approve a merger (69 percent), amend the corporate charter or bylaws (37 percent), or remove directors (64 percent); the presence of a poison pill (14 percent) or golden parachute (53 percent); indicators for the presence of blank-check preferred stock (93 percent); a fair-price provision (6 percent); a provision allowing the board to consider

${ }^{29}$ Dummies for property type and pre-IPO status were never significant in these or subsequent regressions. 
stakeholders' interests (13 percent); restrictions on the ability to call for a shareholders' meeting (15 percent); unequal voting rights ( 3 percent); and miscellaneous antitakeover provisions, such as a requirement that directors may be removed only for cause ( 49 percent).$^{30}$ We also collected three variables that are present for all firms in the sample and are thus excluded from our index: an antigreenmail provision (one of the original Gompers, Ishii, and Metrick measures), an excess-share provision, and a provision that declares that the board can change its strategy without the shareholders' approval. Other variables included in the original Gompers, Ishii, and Metrick index either were inapplicable to REITs or could not be determined from the REITs' prospectuses.

As a robustness check, we also construct a measure that is very similar to that developed in Bebchuk, Cohen, and Ferrell (2005), EntrenchIndex, which is a subset of six of the charter provisions of Gompers, Ishii, and Metrick (2003) that they suggest more parsimoniously captures the relation between governance and firm value. Specifically, EntrenchIndex counts the incidence of six provisions: indicators for the presence of a staggered board; provisions requiring a supermajority to approve a merger, amend the corporate charter or bylaws, or remove directors; and the presence of a poison pill or golden parachute. ${ }^{31}$ Finally, for the reasons detailed in Section 2, we construct an indicator variable for incorporation in the state of Maryland (Maryland). ${ }^{32}$

\subsection{Control Variables}

In the following regressions, we use dummy variables for each year (not reported in the tables) to control for time-series variation, including potentially unobservable variables (for example, overall movement of the real estate market, changes in preferences toward REITs, or trends toward tighter governance). The reported coefficients on the remaining independent variables should thus be interpreted as measuring relations due to within-year effects. For example, if we find a positive relation between our valuation measure, $Q$, and our measure of variable pay, then the interpretation is that positive deviations from the average variable pay across that year's REIT IPOs are associated with positive deviations in $Q$ from that year's mean.

To control for the need for monitoring or incentives, we calculate the years of real estate experience for each REIT CEO as of the IPO date, CEOExperience. We would expect that the market may know more about more experienced CEOs and better trust their judgment, and more experienced CEOs may have more

\footnotetext{
${ }^{30}$ See Gompers, Ishii, and Metrick (2003) for further clarification.

${ }^{31}$ Bebchuk, Cohen, and Ferrell (2005) have separate indicators for supermajority requirements for amending the corporate charter or bylaws, while we are unable to separate these two and use one combined indicator. In lieu of this separate variable, we include supermajority requirements for director removal, another measure of the degree to which a firm requires a supermajority to enact a change in firm governance.

${ }^{32}$ We also investigated the size and composition of the board of directors as additional governance variables. Neither was significant in any of our tests, and their inclusion had no meaningful effect on our results.
} 
human capital at risk in their reputations. Both of these effects may suggest less of a need for monitoring or incentives or, alternatively, a higher firm valuation holding governance choices constant.

As additional controls, we calculate the market capitalization based on the IPO offer price, MktCap, the proceeds raised in the IPO, IPOAmt, and a leverage measure, MktLev, the book value of total debt divided by the sum of the offer price value of equity and total debt. To control for the aforementioned REIT industry idiosyncrasies, we construct two indicator variables based on organizational form choices: an indicator for self-administered REITs, SelfAdmin, and an indicator variable for umbrella limited partnership REITs (UPREIT). While we discuss above the tax advantages to UPREITs (which would predict a positive impact on valuation), this structure creates two classes of shareholders, REIT shareholders and OP holders, which may present conflicts of interest (see, for example, Han 2006). The sign of the coefficient on this control will indicate whether the tax advantages or incentive problems are stronger at the time of an IPO. If the tax advantages of UPREITs outweigh the potential conflicts, then we would expect a positive relation between UPREIT status and Q. As mentioned above, we also control for REITs' tax status by including an indicator variable for new REITs (New) and an interaction between New and UPREIT.

\section{Results}

Table 1 shows the distribution of our sample of 107 IPOs over the period 1991-98. The majority of our sample is drawn from 1993 and 1994. The average and median Tobin's $Q$ measures (based on the offer price) tend to decline after 1993. The average and median initial-day returns are positive, except for 1991, a year with only one IPO, and are highest at the end of our sample period. The variation in the number of IPOs and $Q$ over the sample years further justifies our use of year dummy variables in subsequent tests.

Table 2 presents summary statistics for the pooled sample. The average REIT IPO in our sample has a $Q$ of about 1.3 on its IPO date. The average and median adjusted initial-day returns are positive. The median insider-holding percentage is 15.4 percent. ${ }^{33}$ The median amount of CEO experience is 18 years. The majority of our IPOs are UPREITs ( 68 percent), self-administered ( 88 percent), and incorporated in Maryland (68 percent). The median amount of capital raised in this IPO sample is $\$ 151$ million. The median leverage is moderate, at 36 percent of total market capitalization.

Table 2 also presents summary data on our governance and compensation variables. The median amount of compensation that is variable (VarPay) is 22.9 percent. Because the excess-compensation variable is the residual from the regression described in Section 3, it has a mean value of zero. The median values

${ }^{33}$ Because of a couple of outliers, this variable is Winsorized at the second percentile. It is the only variable analyzed that required this. 
Table 1

Equity Real Estate Investment Trust Initial Public Offerings (IPOs) by Year

\begin{tabular}{cccccc}
\hline Year & Number of IPOs & Q IPO Mean & Q IPO Median & AdjRet $_{0}$ Mean & AdjRet $_{0}$ Median $^{\prime}$ \\
\hline 1991 & 1 & 1.187 & 1.187 & -.034 & -.034 \\
1992 & 4 & 1.009 & 1.076 & .014 & .001 \\
1993 & 32 & 1.426 & 1.291 & .047 & .007 \\
1994 & 38 & 1.27 & 1.286 & .034 & .014 \\
1995 & 4 & 1.375 & 1.297 & .002 & .006 \\
1996 & 6 & 1.179 & 1.103 & .034 & .038 \\
1997 & 16 & 1.166 & 1.161 & .055 & .047 \\
1998 & 6 & 1.048 & .998 & .067 & .073 \\
Total & 107 & 1.272 & 1.237 & .04 & .013 \\
\hline
\end{tabular}

of our governance indexes, CharterIndex and EntrenchIndex, are 5 and 3, respectively.

Estimated correlations of our valuation and governance variables are shown in Table 3. The point estimates of the univariate correlations generally support our agency-cost hypotheses but are largely insignificant. Two variables are significantly correlated with Q: Maryland, which is significantly negatively correlated at the 1 percent level, and CEO experience, which is positively correlated at the 5 percent level. While initial-day returns are not our primary interest, we find significant positive correlations (at the 1 percent level) with excess compensation and variable pay and a significant negative correlation (at the 10 percent level) with incorporation in Maryland. The correlation between our two governance indexes is nearly 90 percent.

\subsection{Initial Public Offering Valuation and Governance Characteristics}

To extend the findings of Table 3 to a multivariate setting, in Table 4 we relate Tobin's $Q$ (at the offer and at the closing price) to our governance variables. As noted above, dummies for each sample year are used in the regressions but are not reported. The columns show the results using our two alternative governance indexes for the offer and closing IPO prices. The coefficients for our controls are also reported.

Consistent with our primary hypothesis (that is, firms with stronger governance have higher valuations), column 1 shows that each of our incentive variables has a significant effect on $Q$ based on the offer price. The level of insider ownership and variable pay have positive effects on $Q$ (at the 1 and 5 percent levels, respectively), while the squared insider ownership variable has a negative effect on $Q$ (at the 1 percent level). The coefficients on insider ownership are suggestive of the "roof-type" relation found in Mørck, Shleifer, and Vishny (1988) and Han (2006). For example, the coefficients imply that insider ownership beyond 32.3 percent reduces firm value instead of increasing it. This is further evidence of the entrenchment hypothesis of Stulz (1988) and Mørck, Shleifer, and Vishny (1988). 
Table 2

Summary Statistics

\begin{tabular}{lccccrr}
\hline Variable & Mean & $\begin{array}{c}25 \text { th } \\
\text { Percentile }\end{array}$ & Median & $\begin{array}{c}75 \text { th } \\
\text { Percentile }\end{array}$ & SD & $N$ \\
\hline$Q_{\text {IPO }}$ & 1.272 & 1.113 & 1.237 & 1.394 & .272 & 107 \\
$\ln \left(Q_{\text {IPO }}\right)$ & .219 & .107 & .212 & .332 & .209 & 107 \\
AdjRet $_{0}(\%)$ & 4.00 & .10 & 1.30 & 5.90 & 8.40 & 107 \\
InsiderOwn (\%) $_{\text {ExcessComp (\$ millions) }}$ & 20.10 & 7.60 & 15.40 & 26.40 & 16.80 & 107 \\
VarPay (\%) & 0 & -1.29 & -.34 & .99 & 2.22 & 107 \\
Maryland & 23.80 & 2.20 & 22.90 & 36.90 & 22.10 & 105 \\
EntrenchIndex & .68 & 0 & 1 & 1 & .47 & 104 \\
CharterIndex & 3.07 & 2 & 3 & 4 & 1.38 & 107 \\
CEOExperience & 4.86 & 4 & 5 & 6 & 1.88 & 107 \\
MktCap (\$ millions) & 19.75 & 13 & 18 & 25 & 8.75 & 107 \\
MktLev & 293.27 & 119.28 & 202.23 & 349.24 & 368.63 & 107 \\
IPOAmount (\$ millions) & .35 & .2 & .36 & .48 & .19 & 107 \\
SelfAdmin & 176.74 & 92.3 & 151.1 & 229.5 & 132.27 & 107 \\
UPREIT & .88 & 1 & 1 & 1 & .33 & 107 \\
New & .68 & 0 & 1 & 1 & .47 & 107 \\
\hline
\end{tabular}

Note. Statistics are for a sample of 107 equity real estate investment trust initial public offerings, 1991-98.

The positive coefficient on the proportion of pay that is tied to performance is consistent with investors pricing not only the stock of incentives but also the flow. Our two measures of the degree to which management has adopted provisions that insulate them from market pressures are significantly negatively related to Q: Maryland at the 1 percent level and EntrenchIndex at the 5 percent level. This suggests that firm value is lower in management-friendly states of incorporation and is decreasing with the number of management-friendly charter provisions that a firm has in place. Thus, the message that comes across clearly from this first regression is that governance choices are significantly related to firm value as of the IPO date; all of the governance variables except one are related to $Q$, and that one, ExcessComp, might also be a proxy for unobservable CEO ability.

Inspection of the coefficients on the control variables reveals that $\mathrm{CEO}$ experience is positively related to $Q$ and is significant at the 1 percent level, consistent with the market being willing to pay more for a firm run by a more experienced CEO, perhaps because of a lesser need for monitoring or incentives. In addition, both self-administered REITs and UPREITs have higher initial valuations. The point estimates of the coefficients on New and UPREIT $\times$ New have the expected signs on the basis of tax explanations, but only the former is statistically significant.

Column 2 replaces the EntrenchIndex with our alternative governance index, CharterIndex. Each of the coefficients that was significant in the first regression remains so and retains its original sign and significance. The CharterIndex variable is also negatively related to $Q$ and is also significant at the 5 percent level. This further reinforces the interpretation of governance as a driver of firm value. 
Table 3

Correlation Matrix

\begin{tabular}{|c|c|c|c|c|c|c|c|c|}
\hline & $\ln \left(Q_{\mathrm{IPO}}\right)$ & AdjRet $_{0}$ & InsiderOwn & ExcessComp & VarPay & Maryland & EntrenchIndex & CharterIndex \\
\hline AdjRet $_{0}$ & $\begin{array}{l}.026 \\
(.79)\end{array}$ & & & & & & & \\
\hline InsiderOwn & $\begin{array}{l}.06 \\
(.54)\end{array}$ & $\begin{array}{r}-.035 \\
(.72)\end{array}$ & & & & & & \\
\hline ExcessComp & $\begin{array}{c}-.135 \\
(.17)\end{array}$ & $\begin{array}{l}.349^{* *} \\
(.00)\end{array}$ & $\begin{array}{l}.046 \\
(.64)\end{array}$ & & & & & \\
\hline VarPay & $\begin{array}{r}.043 \\
(.66)\end{array}$ & $\begin{array}{l}.277^{* *} \\
(.00)\end{array}$ & $\begin{array}{l}.055 \\
(.58)\end{array}$ & $\begin{array}{l}.267^{* *} \\
(.01)\end{array}$ & & & & \\
\hline Maryland & $\begin{array}{c}-.276^{\star *} \\
(.00)\end{array}$ & $\begin{array}{c}-.191^{+} \\
(.05)\end{array}$ & $\begin{array}{c}-.024 \\
(.81)\end{array}$ & $\begin{array}{c}.057 \\
(.56)\end{array}$ & $\begin{array}{c}.028 \\
(.78)\end{array}$ & & & \\
\hline EntrenchIndex & $\begin{array}{r}-.133 \\
(.17)\end{array}$ & $\begin{array}{r}-.027 \\
(.78)\end{array}$ & $\begin{array}{r}.086 \\
(.38)\end{array}$ & $\begin{array}{l}.1 \\
(.3)\end{array}$ & $\begin{array}{l}.052 \\
(.6)\end{array}$ & $\begin{array}{l}.297^{* *} \\
(.00)\end{array}$ & & \\
\hline CharterIndex & $\begin{array}{r}-.067 \\
(.49)\end{array}$ & $\begin{array}{c}-.094 \\
(.34)\end{array}$ & $\begin{array}{l}.198^{\star} \\
(.04)\end{array}$ & $\begin{array}{c}.049 \\
(.62)\end{array}$ & $\begin{array}{c}-.03 \\
(.76)\end{array}$ & $\begin{array}{l}.235^{\star} \\
(.02)\end{array}$ & $\begin{array}{l}.896^{* *} \\
(.00)\end{array}$ & \\
\hline CEOExperience & $\begin{array}{l}.216^{*} \\
(.03)\end{array}$ & $\begin{array}{c}-.071 \\
(.47)\end{array}$ & $\begin{array}{l}.141 \\
(.15)\end{array}$ & $\begin{array}{c}-.06 \\
(.54)\end{array}$ & $\begin{array}{l}.029 \\
(.77)\end{array}$ & $\begin{array}{l}.128 \\
(.2)\end{array}$ & $\begin{array}{l}.15 \\
(.12)\end{array}$ & $\begin{array}{l}.216^{*} \\
(.03)\end{array}$ \\
\hline
\end{tabular}

Note. Pearson correlation coefficients for primary variables of interest for a sample of 107 equity real estate investment trust initial public offerings, 1991-98, are presented. $P$-values are in parentheses.

Statistically significant at the .10 level.

* Statistically significant at the .05 level.

${ }^{*}$ Statistically significant at the .01 level. 
Table 4

Equity Real Estate Investment Trust (REIT) Valuation as a Function of Governance

\begin{tabular}{|c|c|c|c|c|c|c|}
\hline \multirow{3}{*}{$\begin{array}{l}\text { Dependent } \\
\text { Variable }\end{array}$} & \multicolumn{4}{|c|}{ Initial Public Offering (IPO) Valuation Regressions } & \multirow{2}{*}{\multicolumn{2}{|c|}{$\begin{array}{c}\text { Change in IPO Firm } \\
\text { Value per SD } \\
\text { Change ( } \$ \text { Millions) }\end{array}$}} \\
\hline & \multirow{2}{*}{$\begin{array}{c}\ln \left(Q_{\mathrm{IPO}}\right) \\
(1)\end{array}$} & \multirow{2}{*}{$\begin{array}{c}\ln \left(Q_{\mathrm{IPO}}\right) \\
\quad(2)\end{array}$} & \multirow{2}{*}{$\begin{array}{c}\ln \left(Q_{\mathrm{DAY} 1}\right) \\
(3)\end{array}$} & \multirow{2}{*}{$\begin{array}{c}\ln \left(Q_{\mathrm{DAY} 1}\right) \\
(4)\end{array}$} & & \\
\hline & & & & & (5) & $(6)$ \\
\hline InsiderOwn & $\begin{array}{l}1.033^{* *} \\
(3.32)\end{array}$ & $\begin{array}{l}1.005^{\star *} \\
(3.27)\end{array}$ & $\begin{array}{l}1.181^{\star *} \\
(3.64)\end{array}$ & $\begin{array}{l}1.155^{\star *} \\
(3.61)\end{array}$ & 4.243 & 5.653 \\
\hline InsiderOwn ${ }^{2}$ & $\begin{array}{l}-1.714^{\star *} \\
(-3.60)\end{array}$ & $\begin{array}{l}-1.630^{* *} \\
(-3.45)\end{array}$ & $\begin{array}{l}-2.007^{* *} \\
(-4.03)\end{array}$ & $\begin{array}{l}-1.915^{\star *} \\
(-3.90)\end{array}$ & & \\
\hline ExcessComp & $\begin{array}{l}-.005 \\
(-.69)\end{array}$ & $\begin{array}{l}-.006 \\
(-.75)\end{array}$ & $\begin{array}{r}.007 \\
(.87)\end{array}$ & $\begin{array}{r}.006 \\
(.79)\end{array}$ & & \\
\hline VarPay & $\begin{array}{c}.162^{\star} \\
(2.08)\end{array}$ & $\begin{array}{c}.144^{+} \\
(1.86)\end{array}$ & $\begin{array}{l}.236^{* *} \\
(2.91)\end{array}$ & $\begin{array}{l}.216^{* *} \\
(2.68)\end{array}$ & 16.471 & 14.169 \\
\hline Maryland & $\begin{array}{l}-.140^{* *} \\
(-3.85)\end{array}$ & $\begin{array}{c}-.145^{\star *} \\
(-4.08)\end{array}$ & $\begin{array}{l}-.185^{\star *} \\
(-4.88)\end{array}$ & $\begin{array}{l}-.190^{\star *} \\
(-5.14)\end{array}$ & -59.062 & -59.178 \\
\hline EntrenchIndex & $\begin{array}{c}-.027^{\star} \\
(-2.17)\end{array}$ & & $\begin{array}{c}-.029^{*} \\
(-2.17)\end{array}$ & & -16.62 & \\
\hline CharterIndex & & $\begin{array}{c}-.022^{\star} \\
(-2.44)\end{array}$ & & $\begin{array}{l}-.025^{\star *} \\
(-2.68)\end{array}$ & & -17.518 \\
\hline CEOExperience & $\begin{array}{l}.006^{\star *} \\
(3.04)\end{array}$ & $\begin{array}{l}.006^{* *} \\
(3.1)\end{array}$ & $\begin{array}{c}.006^{* *} \\
(2.82)\end{array}$ & $\begin{array}{l}.006^{* *} \\
(2.92)\end{array}$ & 24.173 & 23.635 \\
\hline SelfAdmin & $\begin{array}{c}.143^{\star} \\
(2.57)\end{array}$ & $\begin{array}{l}.137^{\star} \\
(2.5)\end{array}$ & $\begin{array}{l}.175^{\star *} \\
(3.01)\end{array}$ & $\begin{array}{l}.170^{* *} \\
(2.99)\end{array}$ & 69.233 & 64.208 \\
\hline UPREIT & $\begin{array}{l}.084^{*} \\
(1.9)\end{array}$ & $\begin{array}{c}.095^{\star} \\
(2.16)\end{array}$ & $\begin{array}{c}.096^{\star} \\
(2.07)\end{array}$ & $\begin{array}{c}.108^{\star} \\
(2.37)\end{array}$ & 39.549 & 43.641 \\
\hline New & $\begin{array}{c}.129^{+} \\
(1.71)\end{array}$ & $\begin{array}{c}.136^{+} \\
(1.81)\end{array}$ & $\begin{array}{c}.12 \\
(1.52)\end{array}$ & $\begin{array}{r}.127 \\
(1.63)\end{array}$ & 62.465 & 63.608 \\
\hline UPREIT $\times$ New & $\begin{array}{r}.125 \\
(-1.28)\end{array}$ & $\begin{array}{r}.149 \\
(-1.55)\end{array}$ & $\begin{array}{r}.135 \\
(-1.32)\end{array}$ & $\begin{array}{r}.161 \\
(-1.60)\end{array}$ & & \\
\hline Adjusted $R^{2}$ & .49 & .5 & .51 & .53 & & \\
\hline
\end{tabular}

Note. Columns $1-4(N=102)$ detail the regressions of Tobin's $Q$ on descriptive and governance variables for a sample of 107 equity REIT IPOs, 1991-98. The dependent variable for columns 1 and 2 is the Tobin's $Q$ of the IPO at the offer price, while the dependent variable in columns 3 and 4 is an estimate of the $Q$ at the end of the first trading day, adjusted for REIT-market movements during the day. Annual dummy variables for years 1992-98 are included, but their coefficients are not reported. Values in parentheses are $t$-statistics. Columns 5 and 6 present estimates of economic significance. For these columns, for each significant variable, a predicted change in firm value is calculated. First, a base Tobin's $Q$ is calculated using the coefficients in columns 1 and 2, respectively, by assuming that all variables are at their means, except for indicator variables, which are set to zero. Then, a revised implied Tobin's $Q$ is calculated by holding all other variables at their means, but increasing the variable of interest by 1 standard deviation (or to one for indicator variables). The implied change in $Q$ is translated into a change in firm value via a change in the expected IPO price. For InsiderOwn, the effect presented includes the effect of the squared term.

${ }^{+}$Statistically significant at the .10 level.

* Statistically significant at the .05 level.

${ }^{*}$ Statistically significant at the .01 level.

Columns 3 and 4 repeat this analysis but with $Q$ measured at the end of the first trading day. By using a market-determined price rather than the offer price, we move from a price based on underwriters' beliefs about demand (among other factors) to a price that should fully incorporate the market's expectations about the firm (including any governance-related effects). The results are almost precisely the same as those obtained in the first two columns, with even greater 
statistical significance, which indicates that the initial day of trading reinforces the strong link between value and governance structure.

Columns 5 and 6 quantify this analysis by analyzing the effects of a 1-standarddeviation increase in the explanatory variables (or a shift from zero to one for categorical variables) on IPO firm value while holding all other variables at their sample means (or zero for the indicator variables). ${ }^{34}$ These results suggest that governance has a meaningful impact economically in addition to statistically, as well as implying a significant decrease in firm value due to the decision to adopt more management-friendly governance structures. For example, a 1-standarddeviation increase in insider ownership is predicted to increase firm value by about \$4.2-\$5.7 million; this is significant compared to the median firm value at the IPO of $\$ 202$ million. Increasing variable pay by 1 standard deviation has an even larger associated impact, at \$14.2-\$16.5 million, while the impact of changes in corporate charter provisions is significantly negative $(-\$ 16.6$ to $-\$ 17.5$ million). Among the governance variables, the strongest effect is associated with incorporation in Maryland, which changes firm value by approximately $-\$ 59$ million.

Taken in sum, the results of these tests are consistent with our primary hypothesis. We find a positive relation between shareholder-oriented governance structures and IPO valuation. Our measures of incentives - the degree of variable pay, insider ownership-have significant effects, as do our proxies for insulation from external forces and incorporation in Maryland and our indexes of governance.

A number of other control variables were analyzed in this and subsequent tests but proved to have no significant effect on our results. The first is underwriter reputation. A number of studies show that the certification role of the underwriting investment bank can influence the IPO's initial pricing and performance (see, for example, Carter, Dark, and Singh 1998). Using the Loughran and Ritter (2004) underwriter reputation rankings, we find no relation between our dependent variables and underwriter reputation. In addition, controls for the REIT's primary property type (retail, apartment, office, industrial, or hotel), leverage, and market capitalization are never significant, nor are dummy variables capturing the pre-IPO status of the firm.

\subsection{Post-Initial Public Offering Performance}

Having found evidence consistent with governance affecting firm value as of the IPO, we now investigate whether these governance choices are related to post-IPO operating performance. We choose to focus on operating performance in order to avoid many of the complications that arise in using stock-market performance, such as joint hypotheses of market efficiency and models of expected returns. The results of these tests are shown in Table 5, where we measure the impact of IPO governance structure on adjusted operating performance for

\footnotetext{
${ }^{34}$ Performing this analysis on IPO proceeds yields very similar results.
} 
Table 5

Long-Run Operating Performance as a Function of Governance Variables, for Adjusted Return on Book Equity

\begin{tabular}{lcc}
\hline Dependent Variable & $(1)$ & $(2)$ \\
\hline InsiderOwn & $.060^{*}$ & $.060^{\star}$ \\
InsiderOwn & $(1.98)$ & $(1.95)$ \\
& $-.122^{\star}$ & $-.124^{*}$ \\
ExcessComp & $(-2.31)$ & $(-2.30)$ \\
VarPay & .0004 & .0004 \\
& $(.72)$ & $(.71)$ \\
Maryland & $.012^{* *}$ & $.013^{* *}$ \\
& $(2.9)$ & $(2.9)$ \\
EntrenchIndex & $-.012^{*}$ & $-.012^{*}$ \\
& $(-2.02)$ & $(-2.18)$ \\
CharterIndex & .001 & \\
& $(.46)$ & .001 \\
CEOExperience & & $(.76)$ \\
& .0003 & .0003 \\
MktCap & $(.83)$ & $(.79)$ \\
& .00001 & .00001 \\
MktLev & $(1.11)$ & $(1.11)$ \\
& $.058^{* *}$ & $.057^{* *}$ \\
SelfAdmin & $(3.29)$ & $(3.44)$ \\
& .001 & .001 \\
UPREIT & $(.25)$ & $(.2)$ \\
& $.006^{*}$ & $.006^{*}$ \\
New & $(2.4)$ & $(2.22)$ \\
UPREIT $\times$ New & .007 & .007 \\
& $(1.21)$ & $(1.33)$ \\
& -.008 & -.008 \\
Now & $(-1.10)$ & $(-1.20)$ \\
\hline
\end{tabular}

Note. Regressions of operating performance on descriptive and governance variables for a sample of 107 equity real estate investment trust (REIT) initial public offerings (IPOs), 1991-98, for the first 12 quarters following the IPO are presented. The performance measure is adjusted return on book equity, defined as the ratio of net income to book equity adjusted by subtracting the median statistic for all seasoned REITs in that calendar quarter. The $t$-statistics are in parentheses and are based on standard errors from a 1,000-iteration bootstrap. $N=1,196$ and adjusted $R^{2}=.05$ for each regression.

${ }^{\star}$ Statistically significant at the .05 level.

${ }^{*}$ Statistically significant at the .01 level.

the first 12 quarters following the IPO. Our dependent variable is the return on book equity, net of the industry median for seasoned REITs in that quarter. ${ }^{35}$ To give an idea of economic significance when interpreting these results, the mean unadjusted return on book equity for our sample is .02 , or approximately 8 percent per year (the median is similar).

Columns 1 and 2 are very similar. In both, insider ownership is significantly positively related to performance, and the negative sign on its squared value

${ }^{35}$ In order to handle potential nonnormality in the regression errors, we calculate $t$-statistics using bootstrapped standard errors, with 1,000 iterations. 
captures the roof-type relation observed in our earlier analysis. Variable pay is significantly positive at the 1 percent level, and Maryland incorporation again has a negative impact on performance.

In addition, the economic magnitudes of the coefficients imply valuation effects that are roughly in line with those in Table 4. For example, using $Q$, debt, and return on book equity for our average firm and the coefficients in column 2 of Table 5, incorporation in Maryland would lead to a $\$ 7.6$ million increase in net income (assuming that the increase in operating performance is entirely attributable to an increase in net income). Applying a price-to-earnings ratio of 10 times leads to an estimated decrease in market capitalization of $\$ 76$ million. ${ }^{36}$ By comparison, from columns 5 and 6 of Table 4, incorporation in Maryland is expected to lead to a decrease in market capitalization of $\$ 59$ million. The other significant governance variables in Table 5 are the two insider ownership variables, which show the previously noted roof-shaped impact on operating performance, and VarPay, which has a strong positive impact on operating performance. Our governance index measures do not have a significant impact on post-IPO operating performance.

Finally, two of our control variables also have a positive and significant effect on performance: UPREIT status, which indicates that the tax advantages and flexibility in financing associated with an UPREIT structure result in superior operating performance post-IPO, and market leverage.

\section{Conclusions}

The design of governance and monitoring mechanisms is arguably one of the most important issues facing firms when they go public. The choices involved in that design can subsequently influence firm valuation and performance. This study examines various governance and compensation mechanisms in place at the time of a REIT's IPO. We focus on IPOs because any negative valuation effects are directly borne by the firm and its insiders through a reduction in the offering's proceeds. Analyzing the governance structure at the time of the IPO also mitigates the endogeneity problem associated with studies of mature firms.

Our analysis provides strong support for our primary agency hypothesis: a REIT's governance structure at the IPO stage is an important determinant of its initial value and performance. We find that REITs with stronger governance structures not only have higher average Tobin's $Q$ but also outperform their peers in terms of abnormal operating performance. Specifically, we find that higher initial values and better post-IPO operating performance are associated with increases in managerial incentives via insider ownership (up to a point) and increases in variable compensation. Our data also show strong negative

\footnotetext{
${ }^{36}$ We base these multiples on typical price-to-funds from operations multiples reported by Rice (2005), who documents ranges of roughly 10-15 times over the 1990s, and Prudential Real Estate Investors (2003), who estimate that REITs traded at multiples of approximately 11 times from 1993 to 2003.
} 
valuation and operating performance effects for incorporation in Maryland and for firms with more management-friendly corporate charters (as measured by our two governance indexes). Measuring $Q$ at the end of the first trading day only strengthens these results.

Collectively, these results suggest that firms with shareholder-oriented governance structures are rewarded by financial markets at the IPO stage. Conversely, choosing management-friendly structures, including incorporating in a management-friendly state, appears to come at a significant cost. Furthermore, the benefits of strong corporate governance appear to extend to the firm's longer-term performance.

\section{Appendix}

\section{Real Estate Investment Trust Structure}

\section{A1. Tax Characteristics}

The tax code requires that a minimum of 75 percent of a REIT's gross income must come from real estate. A REIT is further restricted to be a passive investment conduit; less than 30 percent of a REIT's income must come from the operation of real estate held less than 4 years and income from the sale of securities held less than 1 year. Real estate investment trusts also cannot engage in active real estate operations, including operating a business, developing or trading properties for sale, or selling more than five properties per year. A REIT is further prohibited from entering into tax-free exchanges to acquire properties.

If these provisions are met, then a REIT is not taxed on its distributed taxable income; income is taxed only at the shareholder level. However, the trust is prohibited from passing through any operating losses to shareholders as a tax credit. Other than these conditions, the organizational structure of a REIT is the same as an ordinary corporation.

\section{A2. Classes of Real Estate Investment Trust Investors}

An important characteristic of the ownership structure of REITs is the umbrella partnership REIT (UPREIT). Both self-administered and advisor REITs can have an UPREIT structure. An UPREIT consists of an operating partnership (OP) and a REIT that owns the OP. The operating partners are issued OP units in exchange for the real estate they sell to the REIT. These units can be converted to REIT shares. In addition to providing more flexibility in raising capital, the UPREIT structure has a tax advantage over traditional REITs in acquiring properties. In particular, holders of existing properties are given partnership shares in the REIT rather than REIT shares. Partnership shares are not taxed until they are converted to REIT shares. However, an UPREIT has the potential for greater conflicts of interest because its structure creates two distinct groups of owners: holders of partnership shares and the REIT shareholders. The interests of these two shareholder groups can differ. For example, new shareholders might want 
to sell properties through partnership shares. The sale would trigger capital gains taxes for shareholders of these partnership shares. Holders of operating partnership units could convert their units into common shares, although this conversion would also trigger a taxable event.

\section{References}

$\rightarrow$ Agrawal, Anup, and Charles Knoeber. 1996. Firm Performance and Mechanism to Control Agency Problems between Managers and Shareholders. Journal of Financial and Quantitative Analysis 31:377-97.

$\rightarrow$ Baker, Michael, and Paul A. Gompers. 2003. The Determinants of Board Structure at the Initial Public Offering. Journal of Law and Economics 46:569-98.

Baranchuk, Nina, Robert Kieschnick, and Rabih Moussawi. 2006. Antitakeover Provisions in IPOs: A Re-examination. Working paper. University of Texas at Dallas, School of Managment, Dallas.

$\rightarrow$ Bebchuk, Lucian A., and Alma Cohen. 2003. Firms' Decisions Where to Incorporate. Journal of Law and Economics 46:383-425.

Bebchuk, Lucian A., Alma Cohen, and Allen Ferrell. 2005. What Matters in Corporate Governance? Working paper. Harvard Law School, Cambridge, Mass.

$\rightarrow$ Brennan, Michael, and Julian Franks. 1997. Underpricing, Ownership and Control in Initial Public Offerings of Equity Securities in the U.K. Journal of Financial Economics 45:391-414.

$\rightarrow$ Burns, Natasha, and Simi Kedia. 2006. The Impact of Performance-Based Compensation on Misreporting. Journal of Financial Economics 79:35-67.

Cannon, Susanne E., and Stephen C. Vogt. 1995. REITs and Their Management: An Analysis of Organizational Structure, Performance, and Management Compensation. Journal of Real Estate Research 10:297-317.

$\rightarrow$ Capozza, Dennis, and Paul Seguin. 2000. Debt, Agency, and Management Contracts in REITs: The External Advisor Puzzle. Journal of Real Estate Finance and Economics 20: 91-116.

$\rightarrow$ Carter, Richard B., Rick Dark, and Ajai Singh. 1998. Underwriter Reputation, Initial Returns and the Long-Run Performance of IPO Stocks. Journal of Finance 53:285-311.

$\rightarrow$ Daines, Robert M. 2001. Does Delaware Law Improve Firm Value? Journal of Financial Economics 62:525-58.

$\rightarrow$ Daines, Robert M., and Michael Klausner. 2001. Do IPO Charters Maximize Firm Value? Antitakeover Protection in IPOs. Journal of Law, Economics, and Organization 17: 83-120.

$\rightarrow$ Damodaran, Aswath, Kose John, and Crocker H. Liu. 1997. The Determinants of Organization Form Changes: Evidence and Implications from Real Estate. Journal of Financial Economics 45:169-92.

$\rightarrow$ Damodaran, Aswath, and Crocker H. Liu. 1993. Insider Trading as a Signal of Private Information. Review of Financial Studies 6:79-120.

$\rightarrow$ Field, Laura C., and Jonathan M. Karpoff. 2002. Takeover Defenses of IPO Firms. Journal of Finance 57:1857-89.

Frye, Melissa. 2002. The Evolution of Corporate Governance: Evidence from Initial Public Offerings. Working paper. University of Central Florida, College of Business Administration, Orlando. 
$\rightarrow$ Gentry, William M., Deen Kemsley, and Chris J. Mayer. 2003. Dividend Taxes and Share Prices: Evidence from Real Estate Investment Trusts. Journal of Finance 58:261-82.

Gillan, Stuart, Jay C. Hartzell, and Laura T. Starks. 2006. Tradeoffs in Corporate Governance: Evidence from Board Structures and Charter Provisions. Working paper. University of Texas at Austin, Department of Finance, Austin.

$\rightarrow$ Golec, Joseph H. 1994. Compensation Policies and Financial Characteristics of Real Estate Investment Trusts. Journal of Accounting and Economics 17:177-205.

$\rightarrow$ Gompers, Paul A., Joy L. Ishii, and Andrew Metrick. 2003. Corporate Governance and Equity Prices. Quarterly Journal of Economics 118:107-55.

$\rightarrow$ Han, Bing. 2006. Insider Ownership and Firm Performance: Evidence from Real Estate Investment Trusts. Journal of Real Estate Finance and Economics 32:471-93.

Hermalin, Benjamin, and Michael Weisbach. 2003. Boards of Directors as an Endogenously-Determined Institution: A Survey of the Economic Literature. Economic Policy Review 9:7-26.

$\rightarrow$ Himmelberg, Charles P., Hubbard, R. Glenn, and Darius Palia. 1999. Understanding the Determinants of Managerial Ownership and the Link between Ownership and Performance. Journal of Financial Economics 53:353-84.

$\rightarrow$ Holmström, Bengt. 1979. Moral Hazard and Observability. Bell Journal of Economics 10: 74-91.

Howe, John, and James Shilling. 1990. REIT Advisor Performance. AREUEA Journal 18: 479-500.

Hsieh, Cheng Ho, and C. F. Sirmans. 1991. REITs as Captive-Financing Affiliates: Impact on Financial Performance. Journal of Real Estate Research 6:179-89.

IDD. 1991-98. Investment Dealers' Digest. New York: IDD.

$\rightarrow$ Jarrell, Greg, and Annette Poulsen. 1987. Shark Repellents and Stock Prices: The Effects of Antitakeover Amendments since 1980. Journal of Financial Economics 19:127-68.

$\rightarrow$ Jenkins, James W. 1980. Incentive Compensation and REIT Financial Leverage and Asset Risk. Financial Management 9:81-87.

$\rightarrow$ Jensen, Michael C. 1986. Agency Costs of Free Cash Flow, Corporate Finance, and Takeovers. American Economic Review 76:323-29.

$\rightarrow$ Jensen, Michael C., and William H. Meckling. 1976. Theory of the Firm: Managerial Behavior, Agency Costs and Ownership Structure. Journal of Financial Economics 4: 305-60.

$\rightarrow$ Jensen, Michael C., and Kevin J. Murphy. 1990. Performance Pay and Top Management Incentives. Journal of Political Economy 98:225-64.

$\rightarrow$ Kallberg, Jarl, Crocker H. Liu, and Anand Srinivasan. 2003. Dividend Pricing Models and REITs. Real Estate Economics 31:435-50.

$\rightarrow$ Kallberg, Jarl, Crocker H. Liu, and Charles Trzcinka. 2000. The Value Added from Investment Managers: An Examination of Funds of REITs. Journal of Financial and Quantitative Analysis 35:387-408.

$\rightarrow$ Kim, Moonchul, and Jay R. Ritter. 1999. Valuing IPOs. Journal of Financial Economics 53:409-37.

Lan, Yingcong, and Neng Wang. 2004. Investor Protection and Investment. Working paper. Stanford University, Graduate School of Business, Palo Alto, Calif.

$\rightarrow$ Lang, Larry, and René Stulz. 1994. Tobin's Q, Corporate Diversification, and Firm Performance. Journal of Political Economy 102:1248-80.

$\rightarrow$ Ling, David C., and Mark Ryngaert. 1997. Valuation Uncertainty, Institutional Involve- 
ment, and the Underpricing of IPOs: The Case of REITs. Journal of Financial Economics 43:433-56.

$\rightarrow$ Loughran, Tim, and Jay R. Ritter. 2004. Why Has IPO Underpricing Changed over Time? Financial Management 33:5-37.

$\rightarrow$ Mørck, Randall, Andre Shleifer, and Robert W. Vishny. 1988. Management Ownership and Market Valuation: An Empirical Analysis. Journal of Financial Economics 20: 293-315.

NAREIT. 1991-98. REIT Handbook. Washington, D.C.: National Association of Real Estate Trusts.

Prudential Real Estate Investors. 2003. US Market Outlook-Third Quarter 2003. Parsippany, N.J.: Prudential Financial.

Rice, Matt. 2005. REIT Valuations Relative to Other Asset Classes. Working paper. DiMeo Schneider \& Associates, LLC, Chicago.

$\rightarrow$ Shleifer, Andre, and Robert W. Vishny. 1997. A Survey of Corporate Governance. Journal of Finance 52:737-83.

$\rightarrow$ Sinai, Todd, and Joe Gyourko. 2004. The Asset Price Incidence of Capital Gains Taxes: Evidence from the Taxpayer Relief Act of 1997 and Publicly-Traded Real Estate Firms. Journal of Public Economics 88:1543-65.

$\rightarrow$ Smart, Scott B., and Chad J. Zutter. 2003. Control as a Motivation for Underpricing: A Comparison of Dual- and Single-Class IPOs. Journal of Financial Economics 69:85-110.

Solt, Michael E., and Norman G. Miller. 1985. Managerial Incentives: Implications for the Financial Performance of Real Estate Investment Trusts. AREUEA Journal 13:404-23.

$\rightarrow$ Stulz, René M. 1988. Managerial Control of Voting Rights: Financing Policies and the Market for Corporate Control. Journal of Financial Economics 20:25-54.

$\rightarrow$ Subramanian, Guhan. 2001. The Influence of Antitakeover Statues on Incorporation Choice: Evidence on the "Race" Debate and Antitakeover Overreaching. University of Pennsylvania Law Review 150:1795-1873.

$\rightarrow$ Wang, Ko, Su Han Chan, and George Gau. 1992. Initial Public Offerings of Equity Offerings: Anomalous Evidence Using REITs. Journal of Financial Economics31:381-410.

Wang, Ko, John Erickson, and George Gau. 1993. Dividend Policies and Dividend Announcement Effects for Real Estate Investment Trusts. AREUEA Journal 21:185-201.

$\rightarrow$ Yermack, David. 1996. Higher Market Valuation for Firms with a Small Board of Directors. Journal of Financial Economics 40:185-211.

$\rightarrow$ Zhou, Xianming. 2001. Understanding the Determinants of Managerial Ownership and the Link between Ownership and Performance: Comment. Journal of Financial Economics 62:559-71. 